\title{
Impact of Calcium Chloride Dipping and Beeswax Coating on the Sensory Quality and Shelf Life of Nectarine (Prunus persica (L.) Batsch var. Nucipersica) Fruits
}

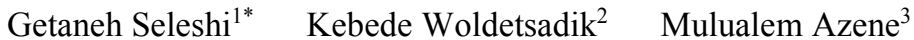 \\ 1.Ethiopian Institute of Agricultural Research, Holeta Research Center. P.O.Box 31. Holeta, Ethiopia \\ 2.College of Agriculture and Environmental Sciences, School of Plant Sciences, Haramaya University, \\ Diredawa, Ethiopia \\ 3.College of Agriculture and Veterinary Sciences, Department of Horticulture, Ambo University, Ambo, \\ Ethiopia
}

\begin{abstract}
This study was conducted to assess the impact of calcium chloride dipping and beeswax coating on the sensory quality and shelf-life of nectarine fruits. The experiment was done under Holeta, Ethiopia condition since 2018. Nectarine fruits of variety ' $89-16 \mathrm{~N}$ ' were harvested from Holeta Agricultural Research Center orchard and subjected to the combination of four $\mathrm{CaCl}_{2}$ levels $(0,1.5,3.0$ and $4.5 \%)$ and three levels $(0,3$ and $6 \%)$ of beeswax. The experiment was arranged in a completely randomized design with factorial arrangement in three replications. All the treatments were stored at ambient condition. The data were collected every five days interval. The results revealed that $\mathrm{CaCl}_{2}$ dipping and beeswax coating had positively influenced the sensory quality and shelf-life of nectarine fruits. The best results were consistently obtained from the combination of $4.5 \% \mathrm{CaCl}_{2}$ and $3.0 \%$ beeswax for most of the sensory quality attributes and storage periods. Therefore, $\mathrm{CaCl}_{2}$ dipping and beeswax coating particularly, $4.5 \% \mathrm{CaCl}_{2}+3 \%$ beeswax, could be considered for maintaining the sensory quality and extending the shelf-life of nectarine fruits.
\end{abstract}

Keywords: Beeswax, $\mathrm{CaCl}_{2}$, coating, nectarine, sensory, shelf-life

DOI: $10.7176 / \mathrm{JNSR} / 11-21-03$

Publication date: November $30^{\text {th }} 2020$

Significance of the study

This study will be contributed to the existing literature by assessing the influence of calcium chloride dipping and beeswax coating on the sensory quality and shelf life of nectarine fruits.

\section{Introduction}

Nectarine is a climacteric fruit, which softens and deteriorates quickly at ambient temperature. Nectarine, like other stone fruits, cannot endure long post-harvest handling periods at normal atmospheres. It is a delicate fruit characterized by high perishability due to rapid softening. This restricts drastically its storage potential and enhances post-harvest loss (Robertson et al., 1990; Lurie and Crisosto, 2005).

Post-harvest losses of fruits and vegetables are estimated between 37 and 55 percent globally (Gustavsson et al., 2011), which are also estimated as high as 50\% for perishable crops in Ethiopia (FAO, 2004). Minimizing postharvest food losses can therefore help to conserve resources and improve human well-being by contributing to food and nutrition security. It can be minimized by extension of shelf-life through checking the rate of transpiration, respiration, microbial infection and protecting membranes from disorganization. To ensure optimum post-harvest quality, stone fruits like nectarines should be protected from excessive post-harvest moisture loss (Bisen and Pandey, 2008; Crisosto and Day, 2012).

Fruit coatings are among the alternatives that do not only improve external appearance but also modify the internal atmosphere of the fruits. It is also an alternative technology to increase the storage life of fresh fruits where there is no cold or refrigerated storage. Coatings used to reduce moisture loss, transpiration, respiration and microbial attack by maintaining fruit firmness at ambient storage condition (Patel et al., 2011; Trang et al., 2011). Using these coatings form good oxygen and lipid barrier during low to intermediate relative humidity since the polymers can effectively make hydrogen bonds (Sihag et al., 2005). On the other hand, positive effects of postharvest calcium chloride application are also reported by many studies and recently receiving considerable attention, since it delayed the ripening and senescence, reduced respiration, extended shelf life, maintains firmness as well as reduced physiological disorders of many fruits and vegetables (Akhtar et al., 2010; Senevirathna and Daundasekera, 2010). Generally, the significance of edible coatings and calcium application on the postharvest quality and shelf-life of fruits have been reported by many studies. However, information related to the combined effect of these treatments, particularly on the sensory quality and shelf life of nectarine fruits is lacking. Hence, the present study was initiated to assess impact of calcium chloride dipping and beeswax coating on the sensory quality and shelf-life of nectarine fruits. 


\section{Materials and Methods \\ Experimental site}

The experiment was conducted at Holeta Agricultural Research Center, which is situated $9^{\circ} 00^{\prime} \mathrm{N}$ latitude and $38^{\circ} 29^{\prime}$ E longitude at an altitude of 2400 m.a.s.1., $40 \mathrm{~km}$ west of Addis Ababa along the Ambo road, Ethiopia. The area received a mean annual rainfall of $1100 \mathrm{~mm}$ and has a relative humidity of $60.6 \%$. The main rainy season is from June to September, which accounts $70 \%$ of the rainfall while the remaining $30 \%$ is from February to April. The average annual maximum and minimum temperatures are 22.1 and $6.2{ }^{\circ} \mathrm{C}$, respectively. The soil type in the area is predominantly Nitosol, which is characterized by an average organic matter content of $1.8 \%$, Nitrogen 0.17\%, Phosphorous 4.55 ppm and Potassium $1.12 \mathrm{meq} / 100 \mathrm{~g}$ of soil and pH of 5.24 (HARC, 2004).

\section{Methodology}

The treatments had consisted of $4 \times 3$ factorial combinations of four levels of $\mathrm{CaCl}_{2}(0,1.5,3.0$ and $4.5 \%)$ and three levels of beeswax $(0,3$ and $6 \%)$ that were assigned in a completely randomized design with three replications. Nectarine fruits variety ' $89-16 \mathrm{~N}$ ' were hand harvested at uniform firm ripe stage from 12 years old full bearing orchard of Holeta Agricultural Research Center. The fruits were immediately taken to the laboratory and sorted for equal size, uniform color and free of disease and blemishes. These fruits were washed using tap water and dried with muslin cloth. Thereafter, different levels of $\mathrm{CaCl}_{2}$ were weighed and dissolved with the respective water. Beeswax emulsions of 3 and 6\% were prepared as described by Hassan et al. (2014). Then, nectarine fruits were once dipped at 1.5, 3.0 and 4.5\% calcium chloride solutions for 15 min except the control. Fruits were also coated with different levels of beeswax leaving the control. Whereas for combined applications, fruits were first dipped in $\mathrm{CaCl}_{2}$ solution and drained for 10 min before coating with beeswax. All the fruits were then stored under ambient environmental condition. Ultimately, sixteen panelists that are familiar for eating nectarine fruits were selected from Holeta Agricultural Research Center, Ethiopia and utilized for sensory evaluation. Two fruit samples were selected per plot, divided into eight pieces each and immediately presented to the panelist according to the plot numbers in a randomized order. Firmness were determined subjectively before fruits were cut, based on the whole fruit resistance to slightly applied finger pressure and recoded using a 1 to 5 tactile rating scale where; $1=$ very soft, $2=$ soft, $3=$ moderately soft, $4=$ firm and $5=$ very firm (Robson et al., 1989). Whereas, texture, flavor, taste and overall acceptability were scored using 1-5 hedonic scale where; $1=$ dislike, $2=$ dislike slightly, $3=$ like, $4=$ like very much, and $5=$ like exceptionally (Miller et al., 2005). The data were collected every 5 days' interval.

\section{Data analysis}

The data were subjected to analysis of variance (ANOVA) in CRD with factorial arrangement to determine differences between the treatments (Gomez and Gomez, 1984). The results were analyzed using Statistical Analysis System (SAS) version 9.0. Comparisons of the treatment means were done by the least significant difference (LSD) test at 5\% significance level.

\section{Results and Discussions Firmness}

The results revealed that nectarine fruits had highly significant $(\mathrm{P} \leq 0.001)$ difference in firmness due to the interaction effect of $\mathrm{CaCl}_{2}$ dipping and beeswax (BW) coating (Table 1). The highest firmness score (4.46) on day5 was observed from $0 \% \mathrm{CaCl}_{2}$ with $6 \% \mathrm{BW}$ treated fruits which, however, was statistically similar with the combinations of $3.0 \% \mathrm{CaCl}_{2}$ and $3 \% \mathrm{BW}, 4.5 \% \mathrm{CaCl}_{2}$ and $3 \% \mathrm{BW}, 3.0 \% \mathrm{CaCl}_{2}$ and $6 \% \mathrm{BW}$; and $4.5 \% \mathrm{CaCl}_{2}$ and $6 \% \mathrm{BW}$. However, the control $\left(0 \% \mathrm{CaCl}_{2}+0 \% \mathrm{BW}\right)$ had received the lowest (3.30) on the same day (Table 1). The firmness of control samples was then dropped to 1.88 after 10 days of storage the fruits were discarded from there on, while treatment combinations of $3.0 \% \mathrm{CaCl}_{2}$ and $3 \% \mathrm{BW}, 4.5 \% \mathrm{CaCl}_{2}$ and $3 \% \mathrm{BW}, 0 \% \mathrm{CaCl}_{2}$ and $6 \%$ $\mathrm{BW}$ as well as $1.5 \% \mathrm{CaCl}_{2}$ and $6 \% \mathrm{BW}$ recorded statistically similar with highest values. On day-15, all fruits coated with $6 \%$ beeswax, irrespective of $\mathrm{CaCl}_{2}$ treatment levels were statistically at par and had higher firmness values. Likewise, $3 \%$ beeswax combined with the highest concentration of $\mathrm{CaCl}_{2}(4.5 \%)$ had statistically comparable high firmness value. While combinations of $4.5 \% \mathrm{CaCl}_{2}$ and $3 \%$ beeswax as well as $6 \%$ beeswax alone registered significantly higher firmness than the others, the former further kept fruits firmer than the others. On the $20^{\text {th }}$ and $25^{\text {th }}$ day of storage, fruits coated with $6 \%$ beeswax after treated with $\mathrm{CaCl}_{2}$ had lower firmness values than those coated with $6 \%$ beeswax alone.

Nectarine fruit firmness in general decreased with the advancement of storage periods irrespective of the treatments (Table 1). This, however, had been significantly maintained due to $\mathrm{CaCl}_{2}$ dipping and $\mathrm{BW}$ coating compared with the control. Moreover, fruits treated at $4.5 \% \mathrm{CaCl}_{2}$ with $3 \% \mathrm{BW}$ consistently maintained the highest fruit firmness. Bico et al. (2010) had reported comparable result from the interaction effect of chemical dips and alginate coating with less firmness loss in banana as compared to the control, chemical dips and alginate coating alone after 3 days of storage. The highest firmness loss in control due to accelerate ripening process during storage periods resulted in the degradation of the middle lamella of the cell wall. It is well known that softening of fruits 
can be related to the enzymatic hydrolysis of cell wall components and by a conversion of insoluble proto-pectin's into soluble pectin (Krishna and Rao, 2014). Lee et al. (2003) observed that edible coating such as carrageenan and whey protein isolate, together with calcium chloride combined with some other anti-browning agents can be minimized softening of apple fruits. Modified atmosphere such as wax coating also delayed the ripening process and reduced physico-chemical changes in fruits (Yahia, 2009).

Fruit softening is related to water loss, which is responsible for the decrease of cell turgor of fresh fruit (Yang et al., 2014). The highest firmness loss in control fruits could also be due to the highest loss of moisture as compared to $\mathrm{CaCl}_{2}$ dipping and $\mathrm{BW}$ coating, and hence fruits kept in these treatments were firmer than the control. Water loss can cause flesh softening, fruit ripening, and senescence by ethylene production and other metabolic reactions (Bai et al., 2002). Edible coatings directly affected fruit firmness by delaying ripening process and decreasing the activity of cell wall degrading enzymes. It is well known that calcium directly affected fruit firmness; the incorporation of calcium in the edible coating was also proved to be effective (Dhall, 2013). The incorporation of beeswax with firming agents $\left(\mathrm{CaCl}_{2}\right)$ probably created a modified atmosphere on the fruit surface, which then might have retarded the metabolic rate, moisture loss, physico-chemical changes that consequently delayed fruit ripening as well as senescence process.

Table 1. Effect of calcium chloride dipping and beeswax coating on the firmness and texture (1-5 rating scale) of nectarine fruits.

\begin{tabular}{|c|c|c|c|c|c|c|c|c|c|c|c|}
\hline \multicolumn{2}{|c|}{ Treatment } & \multicolumn{10}{|c|}{ Storage period (days) } \\
\hline \multirow{2}{*}{$\begin{array}{l}\mathrm{CaCl}_{2} \\
(\%) \\
(A)\end{array}$} & \multirow{2}{*}{$\begin{array}{l}\text { BW } \\
(\%) \\
(B)\end{array}$} & \multicolumn{5}{|c|}{ Firmness } & \multicolumn{5}{|c|}{ Texture } \\
\hline & & 5 & 10 & 15 & 20 & 25 & 5 & 10 & 15 & 20 & 25 \\
\hline 0 & 0 & $3.30^{\mathrm{h}}$ & $1.88^{\mathrm{e}}$ & - & - & - & $3.46^{\mathrm{a}}$ & $2.63^{\mathrm{ef}}$ & - & - & - \\
\hline 1.5 & 0 & $3.50^{\mathrm{gh}}$ & $3.05^{\mathrm{d}}$ & $2.21^{\mathrm{d}}$ & - & - & $3.08^{b}$ & $3.75^{\mathrm{a}}$ & $2.79^{\mathrm{e}}$ & - & - \\
\hline 3.0 & 0 & $3.63^{\mathrm{fgh}}$ & $3.30^{\mathrm{cd}}$ & $2.34^{\mathrm{d}}$ & $1.63^{\mathrm{d}}$ & - & $3.09^{\mathrm{b}}$ & $3.42^{\mathrm{ab}}$ & $3.80^{\mathrm{cd}}$ & $3.50^{\mathrm{ef}}$ & - \\
\hline 4.5 & 0 & $3.71^{\text {efg }}$ & $3.33^{\mathrm{bcd}}$ & $2.25^{\mathrm{d}}$ & $1.79^{\mathrm{cd}}$ & - & $2.88^{\mathrm{c}}$ & $3.04^{\text {bcde }}$ & $3.84^{\mathrm{c}}$ & $3.63^{\mathrm{d}}$ & - \\
\hline 0 & 3 & $4.05^{\mathrm{bcd}}$ & $3.34^{\mathrm{bcd}}$ & $2.42^{\mathrm{cd}}$ & $1.84^{\mathrm{cd}}$ & - & $2.88^{c}$ & $3.04^{\text {bcde }}$ & $4.09^{b c}$ & $3.63^{\mathrm{d}}$ & - \\
\hline 1.5 & 3 & $4.00^{\text {cde }}$ & $3.75^{\mathrm{abc}}$ & $2.63^{\mathrm{cd}}$ & $2.04^{\mathrm{bc}}$ & - & $3.00^{\mathrm{bc}}$ & $2.96^{\text {cde }}$ & $3.75^{\mathrm{cd}}$ & $3.13^{\mathrm{g}}$ & - \\
\hline 3.0 & 3 & $4.34^{\mathrm{abc}}$ & $3.88^{\mathrm{a}}$ & $2.63^{b c}$ & $2.17^{\mathrm{b}}$ & $1.92^{\mathrm{c}}$ & $2.63^{\mathrm{d}}$ & $3.00^{\text {bcde }}$ & $3.84^{\mathrm{c}}$ & $3.59^{\mathrm{de}}$ & $2.59^{b}$ \\
\hline 4.5 & 3 & $4.38^{\mathrm{ab}}$ & $4.08^{a}$ & $3.04^{\mathrm{a}}$ & $2.67^{\mathrm{a}}$ & $2.88^{\mathrm{a}}$ & $2.38^{\mathrm{ef}}$ & $3.13^{\mathrm{bcd}}$ & $4.54^{\mathrm{a}}$ & $4.25^{\mathrm{a}}$ & $3.46^{\mathrm{a}}$ \\
\hline 0 & 6 & $4.46^{\mathrm{a}}$ & $3.63^{\mathrm{abc}}$ & $2.88^{\mathrm{ab}}$ & $2.59^{\mathrm{a}}$ & $2.54^{\mathrm{b}}$ & $2.46^{\mathrm{def}}$ & $2.84^{\mathrm{def}}$ & $4.38^{\mathrm{ab}}$ & $4.00^{\mathrm{b}}$ & $3.33^{\mathrm{a}}$ \\
\hline 1.5 & 6 & $3.92^{\text {def }}$ & $3.83^{\mathrm{ab}}$ & $2.79^{\mathrm{ab}}$ & $2.00^{\mathrm{bc}}$ & $1.88^{\mathrm{c}}$ & $2.38^{\mathrm{ef}}$ & $3.29^{b c}$ & $3.75^{\mathrm{cd}}$ & $3.21^{\mathrm{g}}$ & $2.50^{\mathrm{b}}$ \\
\hline 3.0 & 6 & $4.21^{\mathrm{abcd}}$ & $3.96^{\mathrm{a}}$ & $2.88^{\mathrm{ab}}$ & $2.09^{b c}$ & $1.84^{\mathrm{c}}$ & $2.50^{\mathrm{de}}$ & $3.13^{\mathrm{bcd}}$ & $3.88^{c}$ & $3.46^{\mathrm{f}}$ & $2.63^{b}$ \\
\hline 4.5 & 6 & $4.17^{\mathrm{abcd}}$ & $3.34^{\mathrm{bcd}}$ & $2.88^{\mathrm{ab}}$ & $2.25^{\mathrm{b}}$ & $1.96^{\mathrm{c}}$ & $2.30^{\mathrm{f}}$ & $2.50^{\mathrm{f}}$ & $3.38^{\mathrm{d}}$ & $3.75^{\mathrm{c}}$ & $2.88^{b}$ \\
\hline \multirow[t]{3}{*}{ Sig. } & $A$ & $* * *$ & $* * *$ & $* * *$ & $* * *$ & $* * *$ & $* * *$ & $*$ & $* * *$ & $* * *$ & ns \\
\hline & $B$ & $*$ & $* * *$ & $*$ & $* *$ & $* * *$ & $* * *$ & $* * *$ & $* * *$ & $* * *$ & $* * *$ \\
\hline & $A^{*} B$ & $* * *$ & $* * *$ & $* * *$ & $* * *$ & $* * *$ & $* * *$ & $* * *$ & $* * *$ & $* * *$ & $* * *$ \\
\hline
\end{tabular}

$B W$ : beeswax; means with the same letter (s) in a column are not significantly different at $P \leq 0.05$ (LSD test); $n s$ : non-significant; Sig.: Significance; *: $P \leq 0.05$; **: $P \leq 0.01$; ***: $P \leq 0.001$.

\section{Texture}

The interaction effect of $\mathrm{CaCl}_{2}$ dipping and $\mathrm{BW}$ coating significantly $(\mathrm{P} \leq 0.001)$ influenced the sensory texture of nectarine fruits. The highest degree of liking (3.46) was scored in control fruit samples while the lowest (2.3) was given for $4.5 \% \mathrm{CaCl}_{2}+6 \% \mathrm{BW}$ at day-5. At day-10, better degree of liking was recorded in $1.5 \% \mathrm{CaCl}_{2}$ treated fruits alone while the lowest was recorded in $4.5 \% \mathrm{CaCl}_{2}+6 \% \mathrm{BW}$. From day 15 onwards, the highest degree of liking was given for $4.5 \% \mathrm{CaCl}_{2}+3 \% \mathrm{BW}$ treatment followed by $6 \% \mathrm{BW}+0 \% \mathrm{CaCl}_{2}\left(\mathrm{Table}^{1}\right)$.

Generally, the degree of liking for texture, which is associated with mouth feel when chewing the flesh, was progressively increased and declined back when storage period advanced irrespective of the treatments. However, calcium chloride dipping and beeswax coating had retained the highest degree of liking up to the end of shelf life, especially fruits treated by $4.5 \% \mathrm{CaCl}_{2}+3 \% \mathrm{BW}$ that received the best liking scores in most of the days. Similar findings was reported by Shyam (2013) using chemical dipping and coating treatments in 'Snow Queen' nectarine fruits. The assessors might be preferred fruits that are crisp, crunchy and easily chewed but not mushy and melted fruits. This could be related to enzymatic hydrolysis and softening of cell wall components with progress of ripening of the fruits. Coatings can improve the texture of the produce by reducing water loss and preventing dehydration. In addition, edible coatings may be improved the mechanical integrity of the fruits (Zhao and McDaniel, 2005). Fruit texture is an organoleptic quality appreciated by the consumer that included fruit firmness, juiciness and crispness. The firmness of fruit is influenced by the stage of physiological development, degree of ripeness, turgidity and damage, an attribute that ought to be maintained during post-harvest handling, transport, storage and processing (Sousa et al., 2007). The coating of fruits can be expected to modify the internal gas 
composition of fruits, especially reducing the oxygen concentrations and elevating carbon dioxide concentration, which might be explained the slower textural changes in the coated fruits (Maftoonazad et al., 2008).

\section{Flavor}

Highly significant $(\mathrm{P} \leq 0.001)$ influence on flavor of nectarine fruits was observed due to the interaction effect of $\mathrm{CaCl}_{2}$ dipping and BW coating (Table 2). Degree of liking score for flavor varied from 2.3 to 4.5. At day-5, the highest liking score of 3.63 was recorded in $3 \% \mathrm{BW}$ alone and $1.5 \% \mathrm{CaCl}_{2}+3 \% \mathrm{BW}$ treated fruits while the lowest (2.3) was given for $4.5 \% \mathrm{CaCl}_{2}+6 \% \mathrm{BW}$. At day-10, the lowest liking score (2.46) was given to control fruit followed by $1.5 \% \mathrm{CaCl}_{2}$ treated fruits whereas the highest (4.09) was recorded in $6 \% \mathrm{BW}+0 \% \mathrm{CaCl}_{2}$ treated fruits. At day-15 and onwards, the highest degree of liking score was maintained in $3 \% \mathrm{BW}+4.5 \% \mathrm{CaCl}_{2} \mathrm{treated}$ fruits.

The flavor of nectarine fruits in general was slightly increased followed by a gradual reduction for most of the treatments over time. However, immersion of $\mathrm{CaCl}_{2}$ and $\mathrm{BW}$ coating maintained flavor better compared with the control. Shyam (2013) reported such a slight increase in flavor rating before exhibiting a decrease during 28 days of storage for treated 'Snow Queen' nectarine fruits. This could be due to $\mathrm{CaCl}_{2}$ dipping and $\mathrm{BW}$ coating that might have restricted the loss of volatile flavor compounds and other functional food ingredients by slowing down the rate of respiration, transpiration and other metabolic activities. Flavor and aroma increased during ripening as a result of production of important volatile compounds and the degradation of bitter compounds such as tannins and flavonoids (Bhattarai and Gautam, 2006; Prasanna et al., 2007). Edible coatings can retard ethylene production and delay the ripening process, thus preventing the development of off-flavor and off-taste during postharvest storage of the produce (Zhao and McDaniel, 2005).

\section{Taste}

The difference in the taste of nectarine fruits was significant $(\mathrm{P} \leq 0.001)$ up to 25 days of storage due to the interaction effect of $\mathrm{CaCl}_{2}$ dipping and $\mathrm{BW}$ coatings. At day-5, the highest taste liking (3.09), which was statistically similar to nearly half of the treatments, was given for $0 \% \mathrm{CaCl}_{2}+3 \% \mathrm{BW}$ fruits while the lowest (2.25) was scored for $4.5 \% \mathrm{CaCl}_{2}+6 \% \mathrm{BW}$. At day-10, the highest liking score of 3.42 was recorded for both $0 \%$ and $1.5 \% \mathrm{CaCl}_{2}+6 \% \mathrm{BW}$ treatments, which were statistically at par with fruits treated by $3 \% \mathrm{BW}$ combined with 0 and $1.5 \% \mathrm{CaCl}_{2}$. At day-15, high taste scores ranged from 3.59 to 3.83 was recorded in fruits treated with $4.5 \%$ $\mathrm{CaCl}_{2}+3 \% \mathrm{BW}, 3.0 \% \mathrm{CaCl}_{2}$ alone and $6 \% \mathrm{BW}$ alone while the lowest $(2.46)$ was in $1.5 \% \mathrm{CaCl}_{2}$ treated fruits. At day-20 and $25,4.5 \% \mathrm{CaCl}_{2}+3 \% \mathrm{BW}$ treated fruits showed highest taste values, which did not vary statistically from treatment of $6 \% \mathrm{BW}$ combined with 0 and $4.5 \% \mathrm{CaCl}_{2}$ while the lowest was observed in fruits treated with lower concentrations of beeswax and $\mathrm{CaCl}_{2}$ (Table 2).

In general, the degree of liking for taste of nectarine fruits showed an initial increase following a gradual decrease as storage period was prolonged. Calcium chloride dipping and beeswax coating had better conserve the taste as compared to the control. The taste score increased for $\mathrm{CaCl}_{2}$ and $\mathrm{BW}$ coating as the fruits ripened and then declined after 15 days of storage in treatments that had marketable fruits. Anjum et al. (2006) reported comparable result in mango fruits treated with edible coatings and Ahmad (2008) in Bartlett pears that were dipped in 8-12\% calcium chloride. This might be due to that compounds related with taste are released with the process of ripening and decrement with senescence due to higher respiration and transpiration loss of volatile compounds. Camelo (2004) explained that fruit taste is the combination of sweet and sour, and this is an indication of ripeness and eating quality. Iglesias and Echeverría (2009) elaborated that in peach organic acids are the major determining factors of fruit taste and, together with the volatiles that are responsible for the aroma, have an impact on the overall eating quality of the fruit. Delayed ripening and senescence, reduced organic acids degradation and loss of volatile compounds due to barrier to air and moisture in $\mathrm{CaCl}_{2}$ and $\mathrm{BW}$ treated fruits probably retained higher taste scores compared to the control. 
Table 2. Effect of calcium chloride dipping and beeswax coating on the flavor and taste (1-5 rating scale) of nectarine fruits.

\begin{tabular}{|c|c|c|c|c|c|c|c|c|c|c|c|}
\hline \multicolumn{2}{|l|}{ Treatment } & \multicolumn{10}{|c|}{ Storage period (days) } \\
\hline \multirow{2}{*}{$\begin{array}{ll}\mathrm{CaCl}_{2} & (\%) \\
(A) & \end{array}$} & \multirow{2}{*}{$\begin{array}{l}\text { BW } \\
(\%) \\
(B)\end{array}$} & \multicolumn{5}{|c|}{ Flavor } & \multicolumn{5}{|l|}{ Taste } \\
\hline & & 5 & 10 & 15 & 20 & 25 & 5 & 10 & 15 & 20 & 25 \\
\hline 0 & 0 & $2.50^{\mathrm{e}}$ & $2.46^{\mathrm{d}}$ & - & - & - & $3.00^{\mathrm{ab}}$ & $2.38^{\mathrm{e}}$ & - & - & - \\
\hline 1.5 & 0 & $3.08^{\mathrm{cd}}$ & $2.50^{\mathrm{d}}$ & $2.38^{\mathrm{f}}$ & - & - & $2.58^{\text {cde }}$ & $3.00^{\mathrm{bc}}$ & $2.46^{\mathrm{e}}$ & - & - \\
\hline 3.0 & 0 & $3.09^{\mathrm{cd}}$ & $3.13^{\mathrm{c}}$ & $2.79^{\mathrm{e}}$ & $2.63^{\mathrm{e}}$ & - & $2.29^{\mathrm{ef}}$ & $3.00^{\mathrm{bc}}$ & $3.13^{\mathrm{d}}$ & $2.58^{\mathrm{e}}$ & - \\
\hline 4.5 & 0 & $3.29^{\mathrm{bc}}$ & $3.75^{\mathrm{b}}$ & $3.04^{\mathrm{de}}$ & $2.88^{\mathrm{de}}$ & - & $2.50^{\mathrm{def}}$ & $3.00^{\mathrm{bc}}$ & $3.13^{\mathrm{d}}$ & $3.04^{\mathrm{de}}$ & - \\
\hline 0 & 3 & $3.63^{\mathrm{a}}$ & $4.00^{\mathrm{ab}}$ & $3.05^{\mathrm{de}}$ & $2.88^{\mathrm{de}}$ & - & $3.09^{\mathrm{a}}$ & $3.25^{\mathrm{ab}}$ & $3.63^{\mathrm{ab}}$ & $3.25^{\mathrm{abcd}}$ & - \\
\hline 1.5 & 3 & $3.63^{\mathrm{a}}$ & $3.75^{\mathrm{b}}$ & $3.00^{\mathrm{de}}$ & $2.84^{\mathrm{de}}$ & - & $3.00^{\mathrm{ab}}$ & $3.25^{\mathrm{ab}}$ & $3.00^{\mathrm{d}}$ & $2.59^{\mathrm{e}}$ & - \\
\hline 3.0 & 3 & $3.59^{\mathrm{a}}$ & $3.84^{\mathrm{ab}}$ & $3.50^{\mathrm{c}}$ & $3.21^{\mathrm{bc}}$ & $2.59^{b c}$ & $2.84^{\mathrm{ab}}$ & $2.63^{\mathrm{de}}$ & $3.17^{\mathrm{d}}$ & $2.59^{\mathrm{e}}$ & $2.30^{\mathrm{c}}$ \\
\hline 4.5 & 3 & $2.38^{\mathrm{e}}$ & $3.80^{\mathrm{b}}$ & $4.25^{\mathrm{a}}$ & $4.54^{\mathrm{a}}$ & $3.46^{\mathrm{a}}$ & $2.75^{\mathrm{bcd}}$ & $2.83^{\mathrm{cd}}$ & $3.59^{\mathrm{abc}}$ & $3.63^{\mathrm{a}}$ & $3.00^{\mathrm{a}}$ \\
\hline 0 & 6 & $3.33^{\mathrm{b}}$ & $4.09^{a}$ & $4.38^{\mathrm{a}}$ & $3.46^{\mathrm{b}}$ & $3.33^{\mathrm{a}}$ & $2.88^{\mathrm{abc}}$ & $3.42^{\mathrm{a}}$ & $3.83^{\mathrm{a}}$ & $3.54^{\mathrm{abc}}$ & $2.63^{\mathrm{abc}}$ \\
\hline 1.5 & 6 & $3.00^{\mathrm{d}}$ & $3.75^{\mathrm{b}}$ & $3.13^{\mathrm{d}}$ & $2.96^{\mathrm{cd}}$ & $2.50^{\mathrm{c}}$ & $2.59^{\text {cde }}$ & $3.00^{\mathrm{bc}}$ & $3.34^{\mathrm{bcd}}$ & $3.08^{\mathrm{cd}}$ & $2.38^{\mathrm{bc}}$ \\
\hline 3.0 & 6 & $3.46^{\mathrm{ab}}$ & $3.84^{\mathrm{ab}}$ & $3.88^{\mathrm{b}}$ & $3.42^{\mathrm{b}}$ & $2.63^{b c}$ & $2.83^{\mathrm{abc}}$ & $3.42^{\mathrm{a}}$ & $3.25^{\mathrm{cd}}$ & $3.58^{\mathrm{ab}}$ & $2.71^{\mathrm{ab}}$ \\
\hline 4.5 & 6 & $2.30^{\mathrm{e}}$ & $3.13^{c}$ & $3.75^{\mathrm{bc}}$ & $3.38^{\mathrm{b}}$ & $2.88^{\mathrm{b}}$ & $2.25^{\mathrm{f}}$ & $2.59^{\mathrm{de}}$ & $3.17^{\mathrm{d}}$ & $3.17^{\mathrm{bcd}}$ & $2.63^{\mathrm{abc}}$ \\
\hline \multirow[t]{3}{*}{ Sig. } & $A$ & $* * *$ & $* * *$ & $* * *$ & $* * *$ & $*$ & $* * *$ & $*$ & $* *$ & $* * *$ & $*$ \\
\hline & $B$ & $* * *$ & $*$ & $* * *$ & $* * *$ & $* * *$ & $* * *$ & $\mathrm{Ns}$ & $* * *$ & $* * *$ & $* * *$ \\
\hline & $A^{*} B$ & $* * *$ & $* * *$ & $* * *$ & $* * *$ & $* * *$ & $* * *$ & $* * *$ & $* * *$ & $* * *$ & $*$ \\
\hline
\end{tabular}

BW: beeswax; means with the same letter (s) in a column are not significantly different at $P \leq 0.05$ (LSD test); ns: non-significant; Sig.: Significance; *: $P \leq 0.05$; **: $P \leq 0.01$; ***: $P \leq 0.001$.

\section{Overall acceptability}

The overall acceptance of nectarine fruits was significantly $(\mathrm{P} \leq 0.001)$ varied due to the interaction effect of $\mathrm{CaCl}_{2}$ dipping and BW coating (Table 3). The highest acceptance score (3.67) was given for $0 \% \mathrm{CaCl}_{2}+3 \% \mathrm{BW}$ while the lowest (2.80) was scored for those treated with $1.5 \% \mathrm{CaCl}_{2}+0 \% \mathrm{BW}$ on day-5. Similarly, on day-10, the highest acceptance (3.38) was given for 3\% BW coated fruits alone while the lowest (2.75) was observed in the control. At day-15, the maximum score (3.25) was given for fruits coated by $6 \% \mathrm{BW}$ without $\mathrm{CaCl}_{2}$ while the minimum score (2.5) was recorded in $1.5 \% \mathrm{CaCl}_{2}+0 \% \mathrm{BW}$. At day-20, fruits coated with $3 \% \mathrm{BW}+4.5 \% \mathrm{CaCl}_{2}$ received the best acceptability score of 3.25 while fruits immersed with $3.0 \% \mathrm{CaCl}_{2}$ and $4.5 \% \mathrm{CaCl}_{2}$ alone recorded the least acceptance score. The highest acceptance score of 2.63 was also given for $4.5 \% \mathrm{CaCl}_{2}+3 \% \mathrm{BW}$ while the lowest was observed both in $3.0 \% \mathrm{CaCl}_{2}+3 \% \mathrm{BW}$ and $4.5 \% \mathrm{CaCl}_{2}+6 \% \mathrm{BW}$ treatments on day- 25 .

Table 3. Effect of calcium chloride dipping and beeswax coating on the overall acceptability (1-5 rating scale) of nectarine fruits.

\begin{tabular}{|c|c|c|c|c|c|c|}
\hline \multicolumn{2}{|l|}{ Treatments } & \multicolumn{5}{|c|}{ Storage period (days) } \\
\hline $\begin{array}{l}\mathrm{CaCl}_{2}(\%) \\
\text { (A) }\end{array}$ & $\begin{array}{l}\mathrm{BW}(\%) \\
\text { (B) }\end{array}$ & 5 & 10 & 15 & 20 & 25 \\
\hline 0 & 0 & $2.96^{\mathrm{ef}}$ & $2.75^{\mathrm{e}}$ & - & - & - \\
\hline 1.5 & 0 & $2.80^{\mathrm{f}}$ & $2.88^{\mathrm{de}}$ & $2.50^{\mathrm{e}}$ & - & - \\
\hline 3.0 & 0 & $3.00^{\mathrm{def}}$ & $2.88^{\mathrm{de}}$ & $2.63^{\mathrm{de}}$ & $2.25^{\mathrm{f}}$ & - \\
\hline 4.5 & 0 & $3.34^{\mathrm{abcd}}$ & $3.00^{\mathrm{cd}}$ & $2.63^{\mathrm{de}}$ & $2.25^{\mathrm{f}}$ & - \\
\hline 0 & 3 & $3.67^{\mathrm{a}}$ & $3.38^{\mathrm{a}}$ & $3.00^{\mathrm{abc}}$ & $2.50^{\mathrm{d}}$ & - \\
\hline 1.5 & 3 & $3.13^{\text {cdef }}$ & $2.88^{\mathrm{de}}$ & $2.75^{\mathrm{cde}}$ & $2.38^{\mathrm{e}}$ & - \\
\hline 3.0 & 3 & $3.29^{\text {bcde }}$ & $2.88^{\mathrm{de}}$ & $3.00^{\mathrm{abc}}$ & $2.63^{c}$ & $2.25^{\mathrm{b}}$ \\
\hline 4.5 & 3 & $3.42^{\mathrm{abc}}$ & $3.25^{\mathrm{ab}}$ & $3.17^{\mathrm{ab}}$ & $3.25^{\mathrm{a}}$ & $2.63^{\mathrm{a}}$ \\
\hline 0 & 6 & $3.63^{\mathrm{ab}}$ & $3.17^{\mathrm{b}}$ & $3.25^{\mathrm{a}}$ & $2.92^{b}$ & $2.50^{\mathrm{ab}}$ \\
\hline 1.5 & 6 & $3.55^{\mathrm{ab}}$ & $3.25^{\mathrm{ab}}$ & $2.88^{\text {bcd }}$ & $2.88^{b}$ & $2.34^{\mathrm{b}}$ \\
\hline 3.0 & 6 & $3.33^{\mathrm{abcd}}$ & $3.25^{\mathrm{ab}}$ & $3.00^{\mathrm{abc}}$ & $2.63^{c}$ & $2.33^{b}$ \\
\hline 4.5 & 6 & $3.29^{\text {bcde }}$ & $3.13^{\mathrm{bc}}$ & $2.63^{\mathrm{de}}$ & $2.50^{c}$ & $2.25^{\mathrm{b}}$ \\
\hline \multirow[t]{3}{*}{ Sig. } & $A$ & $* * *$ & $* * *$ & $* * *$ & $* * *$ & ns \\
\hline & $B$ & $*$ & $* *$ & $*$ & $* * *$ & ns \\
\hline & $A^{*} B$ & $* * *$ & $* * *$ & $* * *$ & $* * *$ & ns \\
\hline
\end{tabular}

BW: beeswax; means with the same letter (s) in a column are not significantly different at $P \leq 0.05$ (LSD test); ns: non-significant; Sig.: Significance; *: $P \leq 0.05$; **: $P \leq 0.01$; ***: $P \leq 0.001$.

Generally, $\mathrm{CaCl}_{2}$ dipping and beeswax coating had better maintained the overall acceptance of nectarine fruits compared to the control. Relatively the best overall acceptance was retained in fruits treated with combination of 
$3 \% \mathrm{BW}$ and $4.5 \% \mathrm{CaCl}_{2}$ for most of the storage periods. This result is in agreement with reports of HernandezMunoz et al. (2008) who observed higher acceptance score in strawberry fruits treated with chitosan coating combined with postharvest calcium treatment and Shariatifar and Jafarpour (2013) who recorded increased sensory quality acceptance in apple fruits treated with edible coatings as compared to the control. This might be due to reduced respiration and transpiration losses, slowing down of fruit ripening and senescence in $\mathrm{CaCl}_{2}$ and $\mathrm{BW}$ treated fruits. This could be conserved volatile compounds responsible for flavor, aroma and taste. The consumer preference might also be related to higher acidity. Higher consumer acceptance was obtained on fruits with a predominant flavor while lack of flavor and ripening are the main cause of fruit rejection (Crisosto and Crisosto, 2006).

The attractiveness of fruit to consumers is also determined by visual attributes that include appearance, size, uniformity, color and freshness, as well as non-visual attributes such as taste, aroma, flavor, texture, nutritional value and healthiness. Among these attributes, texture and aroma appear to be the most important for consumers (Awad and De Jager, 2002; Aaby et al., 2002). The lower acceptability of control fruit samples during storage could, therefore, be due to the loss of volatile compounds responsible for organoleptic taste, flavor and aroma. Early softening, rotting, shriveling and onset of senescence of fruits might also reduce the overall acceptability of control fruit samples.

\section{Conclusions}

Calcium chloride dipping and beeswax coating had positively affected the sensory quality as well as shelf-life of nectarine fruits. Sensory texture of nectarine fruits was varied with storage period. The highest texture score at day-5 was recorded from control fruit samples; it was from $1.5 \% \mathrm{CaCl}_{2}$ treated fruits alone at day-10 while in $4.5 \%$ $\mathrm{CaCl}_{2}+3 \% \mathrm{BW}$ at day-15 and onwards. Similarly, the flavor of nectarine fruits was also better maintained in $4.5 \%$ $\mathrm{CaCl}_{2}$ with $3 \% \mathrm{BW}$ at most of the storage periods. The taste of nectarine fruits on the other hand was best in fruits coated with $6 \% \mathrm{BW}$ without $\mathrm{CaCl}_{2}$ up to day-15. At day-20 and 25, however, the highest taste score was given for $4.5 \% \mathrm{CaCl}_{2}$ with $3 \% \mathrm{BW}$ treatment. Generally, $4.5 \% \mathrm{CaCl}_{2}+3 \% \mathrm{BW}$ treated fruits had the highest overall acceptance in most of the days. Therefore, $\mathrm{CaCl}_{2}$ dipping and beeswax coating of nectarine fruits in general and $4.5 \% \mathrm{CaCl}_{2}+3 \% \mathrm{BW}$ treatment in particular could be considered since consistently maintained better sensory quality and extended the shelf life of fruits.

\section{Acknowledgements}

The authors would like to acknowledge the Ethiopian Institute of Agricultural Research for financing and supporting in the accomplishment of this study. We have also special praise to the researchers, field and laboratory workers as well as technical assistants working in temperate and indigenous fruits research department, Holeta Agricultural Research center.

\section{References}

Aaby, K., Haffner, K. and Skrede, G. (2002). Aroma quality of 'Graven stein' apples influenced by regular and controlled atmosphere storage. Lebensmittel-Wissenschaft und-Technologie, 35: 254-259.

Ahmad, F. (2008). Calcium therapy for prolongation of storage life of pear cv. 'Bartlett'. Applied Biology Research, 10: $17-21$.

Akhtar, A., Abbasi, N. A. and Hussain, A. (2010). Effect of calcium chloride treatments on quality characteristics of loquat fruit during storage. Pakistan Journal of Botany, 42: 181-188

Anjum, N., Masud, T. and Latif, A. (2006). Effect of various coating materials on keeping quality of mango (Mangifera indica) stored at low temperature. American Journal of Food and Technology, 1(1):52-58.

Awad, M. A. and De Jager, A. (2002). Influences of air and controlled atmosphere storage on the concentration of potentially healthful phenolics in apples and other fruits. Biology and Technology, 27: 53-58.

Bai, J., Baldwin, E. A. and Hagenmaier, R. H. (2002). Alternatives to shellac coatings provide comparable gloss, internal gas modification and quality for delicious apple fruit. Horticultural Science, 37: 559-563.

Bhattarai, D. R. and Gautam, D. M. (2006). Effect of harvesting method and calcium on post-harvest physiology of tomato. Nepal Agricultural Research Journal, 7:37-41.

Bico, S. L. S., De Jesus Raposo, M. F., De Morais, R. M. S. C. and De Morais, A. M. M. B. (2010). Chemical dips and edible coatings to retard softening and browning of fresh-cut banana'. International Journal of Postharvest Technology and Innovation, 2(1): 13-24.

Bisen, A., Pandey, S. K. and Joushwa, J. E. (2008). Effect of gamma irradiation, growth retardant and coatings on storability of lime fruits. Asian J Hort, 25:159-163

Camelo, A. F. L. (ed.). (2004). Manual for the preparation and sale of fruits and vegetables: from field to market. Food and Agriculture Organization.

Crisosto, C. H. and Crisosto, G. M. (2006). Segregation of peach and nectarine (Prunus persica (L.)Batsch) cultivars according to their organoleptic characteristics. Postharvest Biology and Technology, 39(1): 10-18 
Crisosto, C. H. and Day, K. R. (2012). Stone fruit. pp. 212-225. In: Crop Post-Harvest: Science and Technology. Blackwell Publishers, United States of America.

Dhall, R. K. (2013). Advance in edible coating for fresh fruits and vegetables: A review, Critical Reviews in Food Science and Nutrition, 53(5): 435-450.

FAO (Food and Agricultural Organization). (2004). The state of the food insecurity in the world. Rome, Italy. Available from: http://www.fao.org/

Gomez, K. A. and Gomez, A. A. (1984). Statistical Procedures for Agricultural Research. John Willey and Sons, New York, United States of America.

Gustavsson, J., C. Cederberg, U. Sonesson, R. Van Otterdijk, and A. Meybeck. (2011). Global Food Losses and Food Waste. Rome: Food and Agriculture Organization of the United Nations.

HARC (Holetta Agricultural Research Centre). (2004). Annual review report.

Hassan, Z. H., Lesmayati, S., Qomariah, R. and Hasbianto, A. (2014). Effects of wax coating applications and storage temperatures on the quality of tangerine citrus (Citrus reticulata) var.'Siam Banjar'. International Food Research Journal, 21(2): 641-648

Hernandez-Munoz, P., Almenar, E., Del Valle, V., Velez, D. and Gavara, R. (2008). Effect of chitosan coating combined with postharvest calcium treatment on strawberry (Fragaria ananassa) quality during refrigerated storage. Food Chemistry, 110: 428-435.

Iglesias, I. and Echeverria, G. (2009). Differential effect of cultivar and harvest date on nectarine color, quality and consumer acceptance. Scientia Horticulturae, 120: 41-50.

Krishna, K. R., and Rao, D. V. S. (2014). Effect of Chitosan Coating on the Physiochemical Characteristics of Guava (Psidium guajava L.) Fruits during Storage at Room Temperature. Indian Journal of Science and Technology, 7(5): 554-558.

Lee, J. Y., Park, H. J., Lee, C. Y. and Choi, W. Y. (2003). Extending shelf life of minimally processed apples with edible coatings and anti-browning agents. LWT-Food Science and Technology, 36(3): 323-329.

Lurie, S. and Crisosto, C. H. (2005).Chilling injury in peach and nectarine. Postharvest Biology and Technology, 37(3): 195-208.

Maftoonazad, N. Ramaswamy, H. S. and Marcotte, M. (2008). Shelf-life extension of peaches through sodium alginate and methylcellulose edible coatings. International Journal of Food Science and Technology, 43(6): 951-957.

Miller, S., Hampson, C. McNew, R., Berkett, L., Brown, S., Clements, J., Crassweller, R., Garcia, E., Greene, D. and Greene G. (2005). Performance of Apple cultivars in the 1995 NE-183 regional project planting III: Fruit sensory characteristics. Journal of American Pomological Society, 59: 28-43.

Patil, S. B., Raut, V.U., Gadekar, A. K. and Patil, S. M. (2011). Effect of packaging and cushioning materials on shelf life of custard apple fruits under different storage conditions. Asian J. Hort., 6 (1): 264-268.

Prasanna, V., Prabha, T. N. and Tharanathan, R. N. (2007). Fruit ripening phenomena: an overview. Critical reviews in food science and nutrition, 47(1): 1-19.

Robertson, J. A., Meredith, F. I., Horvat, R. J, Senter, S. D. (1990). Effect of cold storage and maturity on the physical and chemical characteristics and volatile constituents of peaches cv. 'Crest Haven'. Journal of Agricultural and Food Chemistry, 38: 620-624.

Robson, M. G., Hopfinger, J. A. and Eck, P. (1989). Postharvest sensory evaluation of calcium treated peach fruit. Acta Horticulturae, 254: 173-177.

Senevirathna, P. and Daundasekera, W. (2010). Effect of postharvest calcium chloride vacuum infiltration on the shelf life and quality of tomato (cv. 'Thilina'). Ceylon Journal of Science, 39(1): 35-44.

Shariatifar, M. and Jafarpour, E. (2013). Edible coating effects on storage life and quality of apple. Journal of Basic and Applied Science Research, 3(6): 24-27.

Shyam, G. (2013). Postharvest handling and storage of nectarine (Prunus persica var. nucipersica Schneid). Ph.D. thesis, University of Horticulture and Forestry, Nauni Solan, India.

Sihag, R. P., Behiwal, L. S. and Mehta, P. K. (2005). Effect of postharvest application of potassium permanganate on shelf life of Peach fruit. Haryana J. Hort. Sci., 34 (3-4): 259-260.

Sousa, M. B., Canet, W., Alvarez, M. D. and Fernandez, C. (2007). Effect of processing on the texture and sensory attributes of raspberry (cv. 'Heritage') and blackberry (cv. 'Thorn free'). Journal of Food Engineering, 78(1): 9-21.

Trang, S. T., Nguyen, T. H. P. and Willem, F. S. (2011). Protective effect of chitosan coating and polyethylene film wrapping on postharvest storage of sugar apples. Asian. J. Food Agro Industry, 4(2): 81-90.

Yahia, E. M. (2009). Modified and controlled atmospheres for the storage, transportation, and packaging of horticultural commodities. CRC Press/Taylor and Francis Group, Boca Raton, Florida.

Yang, G., Yue, J., Gong, X., Qian, B., Wang, H., Deng, Y. and Zhao, Y. (2014). Blueberry leaf extracts incorporated chitosan coatings for preserving postharvest quality of fresh blueberries. Postharvest Biology and Technology, 92: 46-53. 
Zhao, Y. and McDaniel, M. (2005). Sensory quality of foods associated with edible film and coating systems and shelf-life extension. pp. 434-453. In: Han J. H. (ed.) Innovations in food packaging. San Diego, California: Elsevier Academic Press. 